\title{
Death - whose decision? Euthanasia and the terminally ill
}

Sharon I Fraser and James W Walters Loma Linda University, Loma Linda, California, USA

\begin{abstract}
In Australia and Oregon, USA, legislation to permit statutory sanctioned physician-assisted dying was enacted. However, opponents, many of whom held strong religious views, were successful with repeal in Australia. Similar opposition in Oregon was formidable, but ultimately lost in a 60-40\% vote reaffirming physician-assisted dying. This paper examines the human dilemma which arises when technological advances in end-of-life medicine conflict with traditional and religious sanctity-of-life values. Society places high value on personal autonomy, particularly in the United States. We compare the potential for inherent contradictions and arbitrary decisions where patient autonomy is either permitted or forbidden. The broader implications for human experience resulting from new legislation in both Australia and Oregon are discussed. We conclude that allowing autonomy for the terminally ill, within circumscribed options, results in fewer ethical contradictions and greater preservation of dignity.

(Fournal of Medical Ethics 2000;26:121-125)
\end{abstract}

Keywords: Physician-assisted suicide; voluntary euthanasia; patient autonomy; religious belief

\section{Introduction}

The first person to choose a statutory sanctioned death with physician assistance was Bob Dent of Darwin, Northern Territory, Australia, who died September 22, 1996. This was possible under the Rights of the Terminally Ill Act which had become effective July 1, 1996 in the Northern Territory. By chance one of us was in Australia and therefore able to observe the resulting furore, which ran the gamut from approval to vociferous condemnation.

In particular, we were struck by a letter dictated by Bob Dent to his wife, outlining why he was making this choice and pleading that this "most compassionate legislation in the world be respected". ${ }^{1}$ He described an incontinent, painracked, totally dependent existence exacerbated by watching the suffering of his wife as she cared for him. He stated that he was "immensely grateful" that he could end his life in a dignified and compassionate manner. In addition he asserted that "the Church and State must remain separate.
What right has anyone because of their own religious faith (to which I don't subscribe) to demand that I behave according to their rules until some omniscient doctor decides that I must have had enough and increases my morphine until I die?"

In this paper we will comment on some of the legal and ethical ramifications of this complex situation. Only physician-assisted death for competent, terminally ill persons will be discussed. Our society believes in the principles of individual autonomy, liberty, justice and democracy. We will argue that the interaction of the traditional valueof-life ethos, certain religious beliefs, and the stark realities of medicine at the end of life, has most commonly resulted in an arbitrary "line in the sand" that is inconsistent with the above principles.

\section{The legality of active euthanasia}

Thirty-four states of the United States, including Washington and Oregon, have statutes explicitly criminalising assisted suicide. One state, Oregon, as the result of a citizen initiative ballot (measure 16), has allowed a specific departure by passing a law permitting physician-assisted death under very restricted conditions. However, because of court challenges, initially no legally sanctioned physician-assisted death occurred. In May 1997, opponents of the law successfully persuaded the lower house of the Oregon legislature to return measure 16 to the voters for possible repeal. The principal opponents to measure 16 are Physicians for Compassionate Care, whose leader is a devout Catholic.

Previously (February 1997), the ninth circuit federal appeals court upheld measure 16 but allowed a stay to remain in effect until a ruling by the US Supreme Court. The Supreme Court ruled in June 1997 (considering also a similar opinion rendered by the second circuit federal appeals court), and effectively refused to grant Americans a constitutional "right to die". "However, their ruling did not preclude states from passing laws that would establish such a right: in fact, five of the nine justices suggested they might 
support such a claim in the future". ${ }^{2}$ Most recently (November 1997) 60\% of Oregon voters rejected the attempt to repeal measure 16 . The federal appeals court lifted the stay barring implementation of the law. Both proponents and opponents of this "only one of its kind in the world" statute predict "the adoption of similar measures in other states". 3

In Australia, the Northern Territory legislation was short-lived. In March 1997, the federal parliament effectively repealed the "state" legislation by passing in the Australian senate the Euthanasia Laws Bill, commonly known as the "Andrews Bill" after its unapologetically doctrinaire architect. A member of the Australian senate, he is also described as a "father-of-five and lawyer in bioethics" . However, draft legislation in the state of South Australia, if passed, will challenge this federal law. Between September 1996 and March 1997 four competent terminally ill persons were able to exercise the right to physician-assisted death. Although criticisms were made claiming the contrary to be true, both the Oregon and Northern Territory laws had exhaustive provisions designed to safeguard the integrity of the legislation and prevent abuse. ${ }^{56}$

Just how did society arrive at the present impasse where we heatedly debate "right-to-die" legislation? In the past most people died relatively quickly as a result of accident or illness. Nowadays, the rapid increase in medical knowledge, technology, and intervention often allows the terminally ill to linger. Despite the advances in palliative care the death process is too often protracted, painful and undignified.

Therefore it is hardly surprising that in both the United States and Australia public opinion polls have consistently supported physician-assisted death. For instance, a 1994 Harris poll found that $73 \%$ of Americans favoured physician-assisted suicide $^{7} ; 75 \%$ of Australians in a 1995 poll supported voluntary euthanasia laws. ${ }^{8}$ In Oregon in a February 1997 poll $61 \%$ answered "yes" to the question: "Shall the law allow terminally ill adult patients the voluntary informed choice to obtain a physician's prescription for drugs to end life?" An indication of social division even in Catholicism is that $50 \%$ of the Catholic voters answered "yes" to the same question."

\section{Physician opinion}

It is difficult to generalise about physician opinion with regard to physician-assisted death. Investigation of current attitudes reveals a complex situation. Recently the Oregon Medical Association changed its formerly neutral stance and specifically opposed measure 16, the 1994 voter referendum legalising physician-assisted death. However, this is possibly a reflection of the intense lobbying by the aforementioned Physicians for Compassionate Care, as previously two-thirds or more of Oregon physicians surveyed favoured a patient's right to obtain a doctor's help in hastening death in certain circumstances. ${ }^{10}$

In Australia (1994), of 1268 physicians on the New South Wales state register surveyed by Baume, et al, 59\% answered "yes" and 3.3\% "it depends" to a question favouring physicianassisted death. ${ }^{11}$ In 1995 the same researchers looked at the question of religious affiliation and the practice of euthanasia and found that attitudes varied significantly according to religious affiliation, with "non theists" most sympathetic. The "theists" who reported a Protestant affiliation were intermediate in their attitudes. Perhaps most interesting was that $18 \%$ of Catholic medical practitioners who responded recorded that they had taken active steps to bring about the death of patients when requested..$^{12}$ In Michigan, the "most important personal characteristic" defining physicians' views against "assisted suicide" was a strong religious affiliation. ${ }^{13}$

\section{Discussion of principles}

Whenever these issues are debated certain terms keep appearing: "autonomy", "liberty", "justice”, and "best interests". For a non-expert to have any hope of understanding these terms, it is necessary to look at current medical reality. The ninth circuit court of appeal judges observed that "today, doctors are generally permitted to administer death-inducing medication, as long as they can point to a concomitant pain-relieving purpose". ${ }^{14}$ Physicians are aware that the medication may have a "double effect", a term which "originates in Roman Catholic moral theology, which holds that it is sometimes morally justifiable to cause evil in the pursuit of good". ${ }^{15}$

The American Medical Association appears, in the following statement, to subscribe to the euphemism of "double effect": "The intent of palliative treatment is to relieve pain and suffering but the patient's death is a possible side effect of the treatment. It is ethically acceptable for a physician to gradually increase the appropriate medication for a patient, realizing that the medication may depress respiration and cause death". ${ }^{16}$ One wonders whether "double effect" really means "double standard". It seems that the debate is actually about who gets to have input into decisions regarding death-one is reminded of the "omniscient doctor" referred to in Bob Dent's final letter. We can only consider a sampling or snapshot of an ethically and legally complex and 
confused situation, but will nevertheless attempt to reach some understanding. Several ethical principles in our society bear on this discussion.

\section{Liberty and individual autonomy}

In the United States autonomy or the principle of individual decision making is highly valued. The "liberty interest", an individual's right of choice, is guaranteed in the Fourteenth Amendment to the United States Constitution. Thus the issue of physician-assisted death is as much about control as about dying. Does a traditionally paternalistic medical profession continue to have the ability to override a competent, terminally ill patient's wishes, to insist on the right to "know best" in this crucial end-of-life decision? It appears quite contradictory that in the United States, at least, the competent terminally ill patient has the right to make a legally binding advanced directive in anticipation of inability to choose withdrawal of treatment (for example gastrostomy tubes), but is not permitted to hasten death by means of additional medication given with physician advice and/or assistance in the final stages of illness.

The ninth circuit judges were not impressed by the argument that physician-assisted suicide is different in kind, not degree. They drew an analogy between the withdrawal of a gastrostomy tube so that the patient starves to death, and prescribing analgesics to relieve pain when these also depress respiration and result in the patient's death. In the former, the cause of death is starvation, and in the latter, provision of analgesics. In neither case did the patient die of the underlying disease or injury. Addressing the issue of physician-assisted suicide, the judges stated: "We see no ethical or constitutionally recognizable difference between a doctor's pulling the plug on a respirator and his prescribing drugs which will permit a terminally ill patient to end his own life... . To the extent that a difference exists, we conclude that it is one of degree and not one of kind". ${ }^{17}$ These judges clearly recognised that some, perhaps many, physicians do discreetly help their patients to die and acknowledge privately that this is so.

If autonomy is a highly valued principle it is logical that patients, especially, and possibly family, should have the right to participate in all endof-life decisions. Why should the most crucial end-of-life decision be arbitrarily barred? The criminalising of physician-assisted suicide is effectively a prohibition of suicide for many terminally ill patients. The judges held that the "liberty interest" should allow competent, terminally ill patients the right to choose the time and manner of their death. They considered that adequately rigorous safeguards could be implemented in the decision process to prevent abuse. "We believe that the possibility of abuse ... does not outweigh the liberty interest at issue". ${ }^{18}$

\section{Justice}

To most people, medical justice means the fair and equal treatment of patients. The current situation has elements of injustice. For instance, often competent, terminally ill patients are too debilitated to take active steps to end their suffering should they choose to do so. As it is an offence in most states for anyone to assist a suicide, many terminal patients are effectively denied private options available to the non-terminally ill.

There is a perception that any change in the status quo will inevitably lead to widespread abuse. This rationale is hard to follow. Why should allowing patients to determine the time and manner of their deaths necessarily lead to widespread abuse and/or injustice, as if there were some cause and effect relationship?

\section{Democracy}

More than $20 \%$ of physicians in both the United States and Australia admit to taking deliberate action to end the lives of particular patients. This situation almost certainly disproportionately benefits the more privileged in society because they are much more likely to have a relationship of trust with a medical practitioner who will discreetly alleviate their suffering. A remark of the former Northern Territory chief minister is of interest. When commenting on the demise of his legislation, he observed that the senators who voted for repeal "belong to that privileged, wealthy group who have access to voluntary euthanasia themselves". ${ }^{19}$

\section{Religious liberty}

The church may be another contributor to injustice in this area. In Michigan approximately 30\% of doctors who opposed assisted suicide did so primarily because of a strong religious identification. ${ }^{13}$ The principal opponents of both the Oregon and Northern Territory legislations were strongly Catholic. A number of other studies suggest that among the general population, fervent religious belief is an important predictor of opposition to physician-assisted death. ${ }^{1320}{ }^{23}$ It is almost a truism that in a free society people must have freedom of religious belief. As the ninth circuit judges state: "Those who believe strongly that death must come without physician assistance are free to follow that creed, be they doctors or patients. They are not free, however to force their 
views, their religious convictions, or their philosophies on all other members of a democratic society, and to compel those whose values differ from theirs to die painful, protracted, and agonizing deaths". ${ }^{24}$

An important factor frequently overlooked is that recognising a right does not automatically require an action. As stated by the judges, patients and physicians should be free to exercise their conscience. If a choice were extended to both patients and physicians, patients would have the ability to select a physician holding views compatible with their own. A climate of secrecy fosters neither justice nor patients' best interests and society should allow choice among circumscribed options.

The plurality of communities in postmodern society results in religious people making various determinations of God's will, rather than presenting a definitive perspective on God. Although many Christians oppose physician-assisted death, a Biblical interpretation that might support this perspective is indicated below.

However, it should be first noted that in the absence of an ultimate religious morality it is dangerous to expect the state to substitute for God. The modern state should establish moral boundaries of permissible behaviour but should also recognise the limitations of secular reasoning. ${ }^{25} \mathrm{On}$ disputed issues, it is not possible to establish simple moral guidelines acceptable or persuasive to all moral or religious communities.

It is not our intention here to develop a moral theology of physician-assisted death, rather to indicate briefly the direction one might follow by noting supportive Biblical perspectives. One example is that of religious freedom. This doctrine is well illustrated in the story of the fall of Adam and Eve. The value of their freedom to choose was deemed greater than the catastrophic loss for all humankind that followed their choice. A second example, the traditional concept of life after death would seem to question the value of ekeing out every moment of life when the whole of existence goes far beyond temporal death. The Bible portrays a God who values quality of life (both personal and communal), as seen in the story of the patriarch, Moses. In the Biblical portrayal of the conclusion of Moses's life, his health, long life and great contribution to the Hebrew people are more eulogised than his death lamented. ${ }^{26}$

\section{Family autonomy}

Another area which appears to contradict "best interests" is the impact of terminal illness on patients' families. First, how people die irrevocably influences how we remember them. Surely few would wish to be remembered or to remember a loved one as helpless, incontinent, pain-racked or sedated, as was graphically expressed in Bob Dent's final letter. Currently it is illegal to assist suicide in two-thirds of the United States. Consequently thinking people who are in unbearable pain die alone (if they commit suicide) because they do not want to put loved ones at risk.

For instance, a leading supporter of the Oregon Death with Dignity Act is prompted in part by the fact that his wife of 49 years committed suicide alone, which resulted in his subsequent investigation by the coroner and police. ${ }^{27}$ When considering the possibility of this kind of investigation the ninth circuit judges observed that almost all who agreed to assist the dying avoided prosecution but would "likely suffer pain and guilt for the rest of their lives". ${ }^{28}$ Likewise those who did not assist often question whether they should have tried to spare their loved ones. "This burden would be substantially alleviated if doctors were authorized to assist terminally ill persons to end their lives and to supervise and direct others in the implementation of that process". ${ }^{28}$ Indeed physician-assisted suicide could prevent some premature suicide, in that patients would know they had control over the time and manner of their death.

\section{Conclusion}

However, back to the Australian scene, where fully legalised active euthanasia has been practised. When the results of the vote in the Australian senate to repeal the Rights of the Terminally Ill Act were announced at 1:00 am on March 24,1997, the sponsoring senator hugged his wife, who was cradling their three-week-old baby. ${ }^{4}$ This is a powerful image - the defeat of "death" in the presence of a new life. At such times an image like this may influence thinking more powerfully than carefully reasoned argument.

However, a close examination of the late twentieth century medical reality reveals that 80 to $85 \%$ of people in the United States die in institutions, $70 \%$ of those after a decision to withdraw or withhold treatment, ${ }^{29}$ and that the great majority of these are elderly. Some recent reports suggest that attitudes to physician-assisted death become more positive with age, ${ }^{21}{ }^{30}$ although this is not a uniform finding. ${ }^{13} 20$ It may be for some that a closer acquaintance with the possibility of death invites further reflection on the question of autonomy. Such a change in attitude could result from the greater wisdom, maturity and tolerance that many people develop as they grow older.

Finally, autonomous individuals will not have uniform opinions. In particular, people will differ 
and change according to age, religion and circumstance. A democratic society that honours justice and liberty should acknowledge and permit these divergent opinions, and allow the terminally ill a degree of freedom as to when and how they die.

Sharon I Fraser, BA, MS, is a Clinical Speech Pathologist and is a Graduate Student of the Faculty of Religion, Loma Linda University, Loma Linda, California, USA. Fames W Walters, PhD, is Professor of Ethics in the Faculty of Religion, Loma Linda University.

\section{References}

1 Dent B. Why I need to die. The Sydney Morning Herald 1996 Sept 27:11 (cols 1-6).

2 Savage D. High Court refuses to grant constitutional 'right to die'. The Los Angeles Times 1997 Jun 27: A-1.

3 Murphy K. Voters in Oregon soundly endorse assisted suicide. The Los Angeles Times 1997 Nov 5: A-1.

The Los Angeles Times 1997 Nov 5: A-1. 4 Gordon M. How euthanasia

5 Oregon Death With Dignity Law. Oregon Revised Statutes 127 800-995.

6 Cordner S. Reactions to Australian state's euthanasia law. Lancet 1995;345:1561-2.

Compassion in Dying v State of Wash 79 F 3d 790 (9th cir 1996): 810-39.

8 Albanese A. A question of human rights. The Sydney Morning Herald 1996 Sept 27: 11 (cols 1-3).

9 Dietz D. Assisted-suicide debate splits catholics The Statesman-fournal. Salem, Oregon, 1997 Mar 11.2A (col 2).

10 Anonymous [newspaper editorial]. Doctors must explain. opposition to Measure 16. The Register-Guard. Eugene, opposition to Measure 16. The
Oregon, 1997 Apr 30:12A (cols 1-2).
11 Baume P, O'Malley, E. Euthanasia: attitudes and practices of medical practitioners. The Medical fournal of Australia 1994; 161:142.

12 Baume P, O'Malley E, Bauman A. Professed religious affiliation and the practice of euthanasia. Fournal of Medical Ethics 1995;21:49-54.

13 Bachman J. Attitudes of Michigan physicians and the public toward legalizing physician- assisted suicide. New England fournal of Medicine 1996;334:303-8.

14 See reference $7: 822$.

15 May W. Double effect. In: Reich W, ed. Encyclopedia of bioethics. New York:The Free Press, 1978:316.

16 See reference $7: 823$

17 See reference $7: 824$

18 See reference 7:837.

19 Ceresa M. Others will follow. The Australian 1997 Mar 24: 2 (cols 5-7).

20 Ward A. Age and acceptance of euthanasia. Fournal of Gerontology 1980;35:421-31.

21 Sedlitz L, Duberstein R, Cox C, Conwell Y. Attitudes of older people towards suicide and assisted suicide: analysis of Gallup poll findings. Fournal of the American Geriatrics Society 1995;43: 993-8.

22 Genuis SJ, Genuis SK, Chang W. Public atttitudes toward the right to die. Canadian Medical Association fournal 1994;150: $701-8$

23 Suarez-Almazor M, Belzile M, Bruera E. Euthanasia and physician-assisted suicide: a comparative survey of physicians, terminally ill cancer patients, and the general population. Fournal of Clinical Oncology 1997;15:418-27.

24 See reference 7:839.

25 Engelhardt HT. In: Engelhardt HT. The foundations of bioethics [2nd ed]. New York: Oxford University Press, 1996: 3-17.

26 The Bible. Deuteronomy: 34:7-12.

27 Leary L. Wife's pain drives leader of right-to-die ballot issue. Spectrum/Portland. Portland, Oregon: 1994 Mar 4: (cols 3-5).

28 See reference 7:836.

29 See reference $7: 812$

30 Littlejohn T, Burrows-Johnson J. An attitudinal survey of euthanasia in Windward Oahu. Hawaii Medical fournal 1996;55:265-9. 